\title{
A Study of Betawi Architecture in Setu Babakan, Jakarta
}

\author{
M. Maria Sudarwani ${ }^{1, a]}$ Galuh Widati ${ }^{1, b]}$ Nousli Betna G.S. ${ }^{2}$ Jessica Putri $^{2}$ \\ Architecture Department of Universitas Kristen Indonesia, Jakarta \\ a], margareta.sudarwani@uki.ac.id \\ b], galuh.widati@uki.ac.id \\ ${ }^{2}$ A Student of Architecture Department of Universitas Kristen Indonesia, Jakarta
}

\begin{abstract}
Betawi is one of the indigenous cultures that inhabit the capital city of Jakarta. This culture was born from a fusion of several cultures that came to the Jakarta area. Betawi culture can be seen from the system of customs that are still preserved such as silat, traditional food, community life, and traditional buildings that are still preserved today. This research used a case study of the Betawi cultural area located in Setu Babakan, Srengseng Sawah, South Jakarta. Setu Babakan area is a stronghold of the Betawi cultural heritage site which is still preserved today. The research objectives of the Betawi architectural concept in the Setu Babakan area are as follows: to know the Betawi architectural Concept, to identify the Betawi architectural concept in the Setu Babakan area, and to find solutions related to the application of Betawi architecture concept in architecture buildings today. The research method used a descriptive method based on empirical facts. The data of this research consisted of primary and secondary data obtained from literature and existing field conditions. Betawi culture as the local culture of the capital city of Jakarta is increasingly marginalized, it is even not the majority in its own area. The results of observations on the site of 879 housing units were divided into original houses as much as $22.75 \%$ characterized the Betawi architecture and $77.25 \%$ did not characterize Betawi architecture. The application of Betawi Architectural Ornaments in the Setu Babakan area, especially seen in the following elements: pendopo or front porch of the house, langkan [Betawi balustrades], hanging lamps, doors, windows, blinds, roofs, and colors.
\end{abstract}

Keywords: aplication, architectural concept, Betawi Architecture, Setu Babakan.

\section{INTRODUCTION}

Indonesia is a country that has a wide cultural diversity which has 17,504 islands. Indonesia has more than 300 ethnic groups in Indonesia, or to be precise 1,340 ethnic groups according to the Indonesian Statistics Bureau (BPS)census in 2010. According to Koentjaraningrat [4], culture has universal elements such as language, knowledge systems, social organizations, living equipment systems, systems livelihoods, religious systems, and the arts. One of the riches of Indonesian culture is the Betawi culture which is the indigenous culture of the capital city of Indonesia. Betawi comes from the word Batavia, previously known as Jayakarta, an area that is an extension of the Demak kingdom. As a coastal area that has an international port, the people who inhabited the Betawi area in the past had many interactions with traders from various regions. These traders came from Java, Malay, Chinese, and Arabic, who later settled and helped enliven the cultural diversity in this region. When the Dutch became the rulers of this 
area, many people from other areas were brought to Betawi lands. This has resulted in a mixture of cultures known to this day with Betawi culture. Architecture is part of the culture which represents the elements of the living equipment system. One of the examples of architecture from a culture in Indonesia is the custom home. Traditional houses are closely related to the daily life attitude of the people. Therefore, the civilization of a culture can be known from its architectural history [6]. According to Harun et al [3 pp.12], the Betawi people generally occupy settlements with yards that are overgrown with fruit trees. It seems that this has also influenced the Betawi traditional houses which use a lot of wood material as a material for structural and non-structural elements of the house in their traditional houses. According to Ching [2] structural elements are elements in a building that function as supports, such as foundations, columns, walls, and floor plans. Meanwhile, non-structural elements are building filler elements, such as dividing walls, doors, and windows. Ornaments as part of traditional house architecture are also often found in traditional Betawi houses. The forms used in ornaments in traditional Betawi houses are quite diverse. Starting from the ornaments in the form of flowers and pre-existing forms. This ornament forms structural and non-structural elements in the Betawi house. Like the ornaments placed on house poles, door frames, fascia board, and others.

Betawi culture is less prominent in the image of the city of Jakarta, where the elements of Betawi cultural ornamentation are very difficult to find in buildings, except for the balang tooth ornaments on shelters, bridges, and city parks. Therefore, it is quite important to raise the theme of Betawi architectural research so that the concept of Betawi architecture can be better understood, especially by the people of Jakarta in general and architects. This research used a case study of the Betawi cultural area located in Setu Babakan, Srengseng Sawah, South Jakarta. Setu Babakan area is a stronghold of the Betawi cultural heritage site which is still preserved today. Areas that belong to the Betawi cultural landscape of Jakarta are Sunda Kelapa, Kota Tua Batavia and Setu Babakan [9]. Betawi cultural diversity can be seen in the Setu Babakan village. Setu Babakan Village offers various recreational facilities that can increase knowledge in getting to know more about Betawi culture. The research objectives of the Betawi architectural concept in the Setu Babakan area are as follows: to know the Betawi architectural Concept, to identify the Betawi architectural concept in the Setu Babakan area, and to find solutions related to the application of Betawi architecture concept in architecture buildings today.

According to Harun et al. [3], the existence of ornaments in Betawi traditional houses shows the influence of various cultures related to Betawi. In general, the Betawi traditional house ornament has a symbol that represents the meaning of the Betawi community. In other words, the attitude of the life of the Betawi people is also influenced by the ornaments used in each traditional house. One of the elements that form the identity that supports culture is architecture. Along with the development of the times, the fact that is quite concerning is that many cultures are threatened with extinction due to the absence of preservation of the current generation. The growing development of foreign cultures colonized this country so that they were able to get rid of the original culture of the nation itself. This fact can not only be seen through changes in social activities and behavior but can be seen in the building in terms of architecture. The development of contemporary architecture is increasingly making traditional architecture marginalized. Currently, it is very difficult to find a building with a traditional Betawi architectural design, even if it is isolated from its area. Jakarta is currently a metropolitan city with towering buildings some slum areas become his trademark.

\section{METHODOLOGY}

The method of this research is a rationalistic approach with a qualitative paradigm. This qualitative rationalistic research approach is in accordance with the nature of the research problem and research objectives. Qualitative Research Method aims to examine the conditions of natural objects, where the researcher is the key instrument. This rationalistic of the qualitative research methodology departs from a holistic approach in the form of a grand concepts which is translated into a substantive theory, the object is researched without being separated from its context in a particular focus / accent, and the results of the research are put back in its grand concept. This type of research focuses on analyzing data through words and pictures by observing the original conditions. The data sources consisted of primary data obtained directly from the field and secondary data obtained from other sources. This research was located in Setu Babakan, Srengseng Sawah, Jakarata Selatan. The data consisted of field notes and photos where the data were analysed in 3 stages of analysis, consisting of data reduction, data modeling, and verification of conclusions. 


\section{RESULT AND DISCUSSION}

The Betawi cultural village area of Setu Babakan has a lake formed naturally with an area of about 25 hectares as the main function of which is a water catchment area and is used as a water tourism object. This village is located in an area in South Jakarta by the Betawi Cultural Village Area Management Unit under the Tourism and Culture Office of the DKI Jakarta Provincial Government. The physical boundaries of the lake / Setu Babakan are as follows: 1) North side: RW 006 and 008 Srengseng Sawah Urban Village; 2) South side: RW 007 Srengseng Sawah Urban Village; 3) East side: RW 006 Srengseng Sawah Urban Village; and 4) West side: RW 008 Srengseng Sawah Urban Village

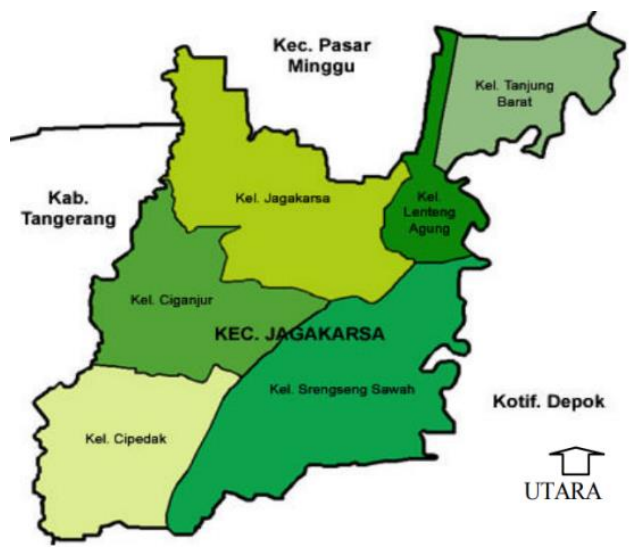

[a]

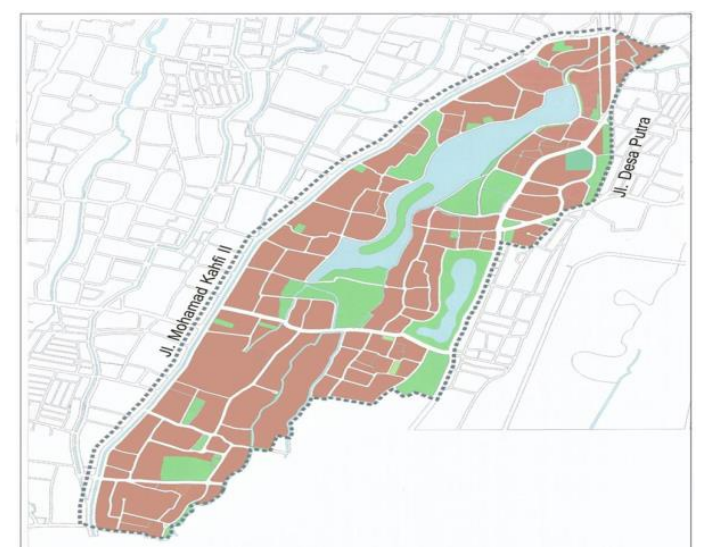

[b]

FIGURE 1. Map of Situ Babakan [8]

\section{History of Setu Babakan Area}

In 1997 in Setu Babakan area, Srengseng Sawah Subdistrict, a "One day at Setu Babakan" event was held, which was carried out by the South Jakarta Municipal Tourism Office and resulted in the planning of the Betawi Cultural Village in Setu Babakan, Srengseng Sawah Village. In 1998, a proposal for a Betawi Cultural Village development plan was submitted to the Provincial Government of DKI Jakarta with an alternative location in Setu Babakan Srengseng Sawah, Jagakarsa District, South Jakarta. On August 8, 2000, the Governor of DKI Jakarta issued the Decree of the Governor of DKI Jakarta Number 92 of 2000 concerning the Environmental Arrangement of Betawi Village. In 2001, Governor Sutiyoso signed the Initial Design Inscription for Betawi Village. In 2005 the Provincial Regulation of DKI Jakarta No.3 of 2005 concerning the Establishment of Betawi Cultural Village in Srengseng Sawah Village, Jagakarsa District, South Jakarta to completely cover the Setu Babakan PBB Development so that its development can be more coordinated and better organized in the future. come.

\section{Spatial Pattern of Setu Babakan Area}

The settlement pattern in the Betawi Cultural Village, Setu Babakan uses a clustered settlement pattern lin a circular shape following Setu Babakan and with the characteristic of the distribution pattern of settlement groups spreading [1]. Settlements in general, settlement patterns in the area can be seen from the layout and orientation of the houses that develop individually. The houses developed are not communal [have certain rules], so they seem irregular. The irregular settlement pattern is a characteristic of the "Betawi Pinggir" or peripheral area of Betawi settlement pattern includes Setu Babakan [5]. The increase in settlement density at this time must be suppressed to avoid changing the character of the area. These changes (a)(b) 45 occur because of various factors of economic needs. The need for easy access to the main road, resulting in a change in the orientation of the settlement pattern [the inner pattern becomes the outer pattern]. Figure 18 shows a sketch of settlement patterns in the Betawi Cultural Village area in general, while Figure 19 shows a sketch of the outer settlement pattern and the inner settlement pattern. The settlement pattern in Setu Babakan consists of two characters:

1. The outer settlement pattern is close to the main road with the following characteristics: a) The orientation of the houses generally faces the main road and turns their backs to the yard, b) 
houses line up along main roads are far apart, but sometimes close together, c) houses are bordered by hedgerows, but sometimes they are bordered by trees and have large yards.

2. Inner settlement pattern faces the yard/garden or neighborhood road. Houses are lined the neighborhood streets. The road is 3 meters wide. The mass of the building tends to be oriented towards the street with the back facing the garden or open space. However, sometimes the houses are grouped close to each other so that it looks very crowded. The boundaries of the yard are bordered by hedges or "Jaro fences" (bamboo). Currently, the yard boundaries have used permanent fences such as iron fences and brick walls

\section{Betawi Architecture}

Every architectural work always has the characteristics and cultural values that it embraces. When carefully observing and recognizing the condition of society, several architectural works will certainly recognize the cultural characteristics of the community. Architecture grows from the influence of a mixture of cultures, because the Betawi people themselves are the result of a mixture of various cultural backgrounds. This mixing is what creates residential architecture with various types of houses as well as architectural elements such as decorations, layouts, structures, and their details. Traditional Houses of the Betawi Tribe:

1. The warehouse house has a rectangular floor, the kitchen is only an addition, the gable extends from front to back, while the roof of the kitchen is often only an additional roof (table roof), with the highest part attached to the inner wall, and tilted towards the back. Warehouse type is generally found in remote areas with buildings that are still in beautiful shape. The shape of this house is rectangular with quite varied sizes. The barn house is inspired by a Portuguese barn, with a roof shaped like a saddle or a shield and a distinctive easel frame. This traditional house also has a sloping roof or is known as markis or hat. This roof functions as a barrier to rainwater and sunlight. The house is also divided into 2 parts. Some parts, namely the front for guests and the middle that is used by homeowners as a place to gather with family

2. Joglo house, a square plan, whose roof is influenced by the shape of the roof of a Javanese house, but not like a pure Joglo because the Betawi house has additional bend (in Sundanese it is called "sorondoy"). The Joglo house in the Betawi traditional house is almost the same as other Javanese joglo houses, this can be seen on the roof of the house. The part that becomes the difference in this house is the location of the support poles which are generally found in jogjo houses in Yogyakarta and Central Java. The structure of the horses used in this house is the structure of the usual horses. The Joglo Betawi house is divided into three rooms consisted of the front room, the living room, and the backroom which are usually owned by priyayi or aristocrats. The front room which is usually with a large terrace to welcome guests, the living room is used to spend time with family and relatives, the bedroom is a place to rest and the dining room.

3. Bapang/Kebaya house, a rectangular plan, a saddle-shaped roof that is folded [has two angles of inclination]; and one of the traditional houses of the Betawi tribe is the kebaya house. The house that is identical to the saddle-shaped roof is folded and when viewed from the side it resembles a kebaya fold. In addition to the kebaya house, other traditional Betawi houses such as the Joglo house, the house on stilts, and the warehouse house. Betawi traditional houses have a characteristic large terrace as a place to interact with family and entertain guests. The Betawi community in ancient times had a cemetery and a well next to the house. The walls of this traditional house have panels made where these panels can be opened and shifted sideways to make the house feel wider. In terms of its nature, the Betawi traditional house can be divided into 2 , consisted of the back which is private which is closed to the public, and the front which is semi-public to describe the beautiful atmosphere of the house.

4. The house on stilts has the shape of a building like a house on stilts with wooden poles as support. This type of traditional house is often found in coastal areas or river basins. The Stage House, one of the traditional houses of the Betawi tribe. Has high support wooden poles and forms a stage. This traditional house is found in the coastal area of the river. The house on stilts was formed to adapt to the environment to avoid the overflowing river, seawater, and wild animals. The house on stilts has a ladder that connects the main building with the outside called "Balak suji" which means as a medium for self-purification before entering the house and as a barrier for disasters into the house. In the construction of a house on stilts, the first thing to do is to choose a location, back to or near a source of flowing water. Furthermore, the hardening of the soil with a house frame consisting of 20 support poles. The foundation structure used is the umpak foundation with a square stone arrangement measuring $20 \times 25 \mathrm{~cm}$. With the pedestal used as the foundation, the supporting poles do not easily enter the ground. The wood that is 
usually used comes from jackfruit, teak, lute, and rambutan wood. The floor base use bamboo while the walls of the house use lined wooden boards. The ceiling of the house use woven bamboo and the roof cover use red tiles. To avoid the blowing of the wind so that it does not immediately enter the entire house, the door leaves are placed more to the left or right side while covering privacy areas such as bedrooms and kitchens.

Position of the Betawi Architecture Building to the ground usually consist of: building attached to the ground, building above the umpak [the pondation]. The Betawi architectural building is characterized by the shape of a grid called gigi balang. which is located on the top of the building. The results of observations on the site of 879 housing units are divided into 1) original 200 houses $(22.75 \%)$ characterized by Betawi architecture, (2) not characterized by Betawi architecture as many as 679 houses $77.25 \%$. From groups that are not characterized by original Betawi architecture, including buildings that have some Betawi ornaments [Fig. 2].

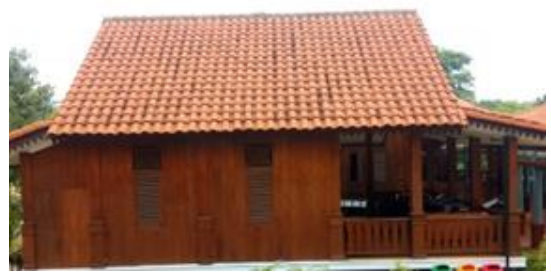

(a)

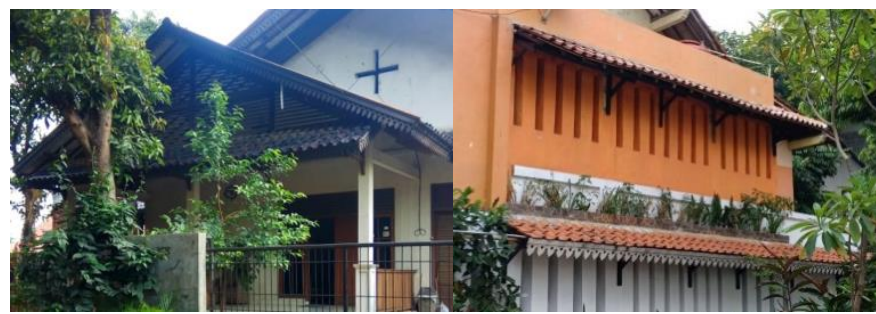

(b)

FIGURE 2. Architectural Diversity in Setu Babakan, (a) Betawi Architecture, (b) Modern Traditionalism (Betawi) Architecture, (c) Modern Architecture.

Betawi architectural ornament is seen in the Setu Babakan area, especially seen in the following elements:

1. Langkan (Ledge). Langkan consists of several boards that decorate the pavilion. The arrangement of the boards is called a ledge. The unique shape and made of wood. Its position is a barrier between the house and the yard. See Fig. 3 .
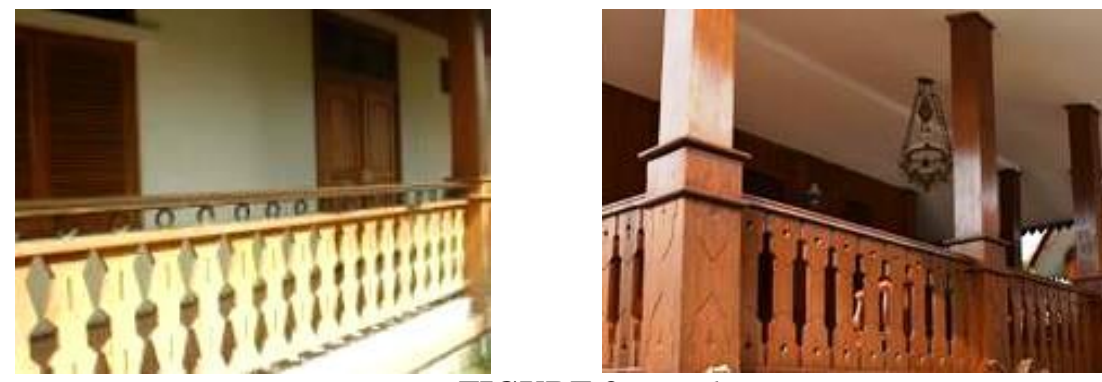

FIGURE 3. Langkan

2. Pendopo or terrace. See Fig.4. The front of the house is a pendopo or terrace. The pendopo area is quite large and is used as an area to welcome guests. We can put a set of tables and chairs in the pavilion area. Usually, the Betawi people place a round table surrounded by four wooden chairs in the area. The terrace symbolizes the Betawi people who easily interact and socialize with other people from different ethnicities, religions, races, or nations.
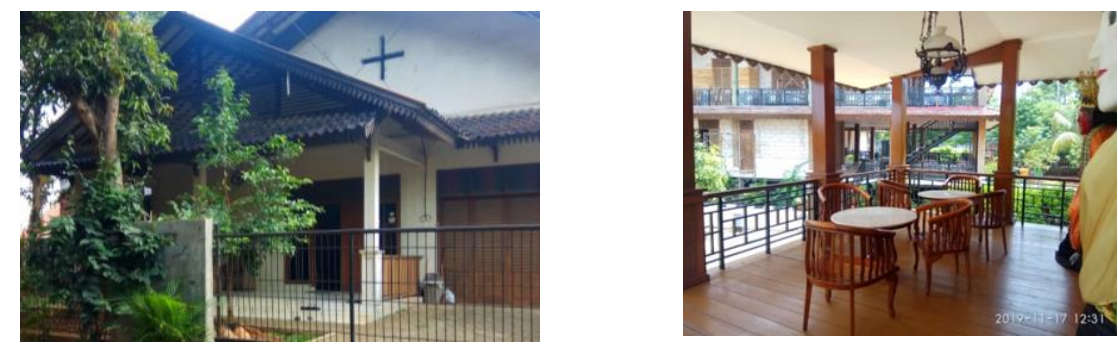
3. Hanging lamps (Fig.5).Many types of lamps are used to decorate the pavilion area. For the most part, the lights are hung in the middle of the airport. There are demand lights, blander lights, and spotlights. The lamp used is quite large and is hung in the middle of the ceiling at the pondopo which is used as an accessory in a traditional Betawi house. Several types are used such as blander lights, spotlights, and demang lights. This lamp uses a copper rope or rope with a color that resembles copper.
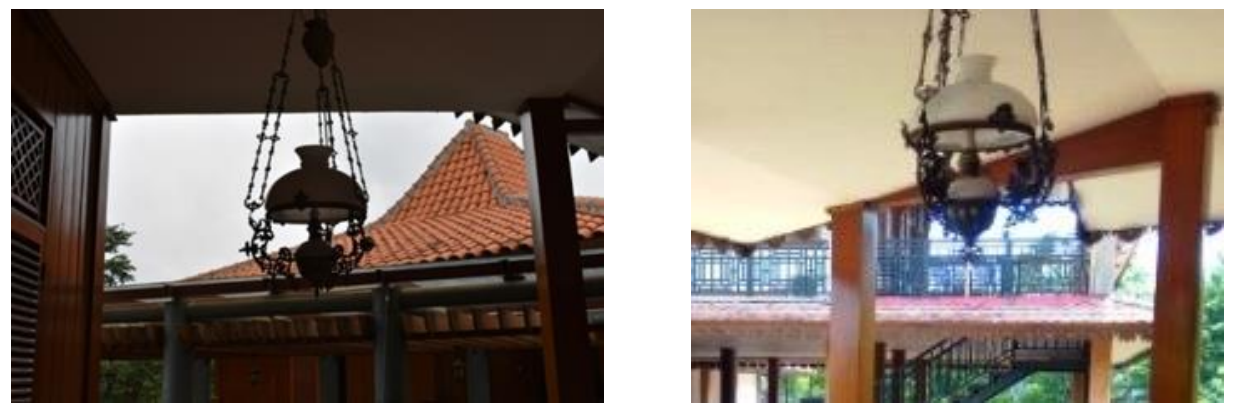

FIGURE 5. Hanging Lamps

4. Doors, vents, and windows (Fig.6). On average, the door at the front of a Betawi house consists of two leaves made of planks. At the top of the door, there is a vent which is also made of boards. laying the door in the middle of the house. While on the left and right there are windows that when opened, point to one side. The doors and windows are wooden frames arranged on an oblique side and horizontal lines. Just is an air hole in the middle of a wooden frame arrangement. The air is also easier to change in the house. The vents are installed over the boards and windows. The goal, air circulation can be maintained properly.

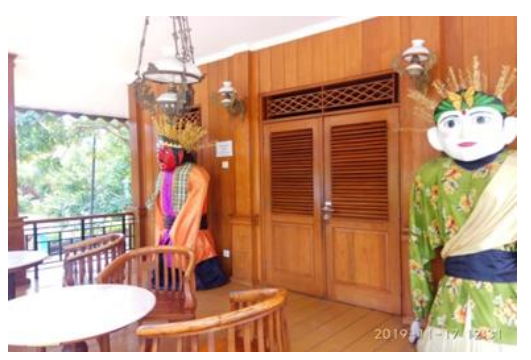

(a)

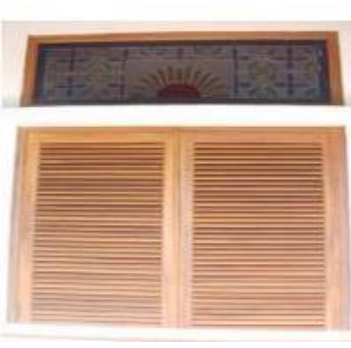

(b)

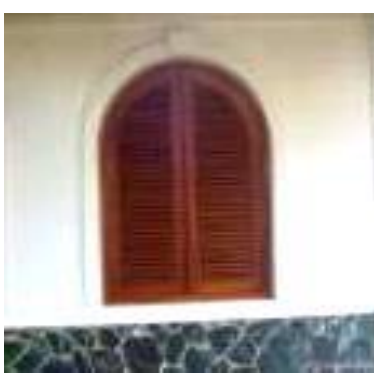

(c)

FIGURE 6. (a) Door, (b) vents, and (c) windows

5. Roof. There is a roof shaped like a saddle with water run off on the front. The house with the roof is called the Kebaya House. When viewed from the side, the roof is in the shape of a kebaya fold. The pyramid-shaped roof is a characteristic of the Joglo House. The shape is influenced by the roof of a Javanese house. Then there is also a saddle-shaped roof but water runoff on the side. This roof is used in stable houses and coastal houses. Each house has a decoration on the edge of the roof or called a lisplang. Usually, the Betawi people use ornamental balang teeth on the fascia board (see Fig.7). 

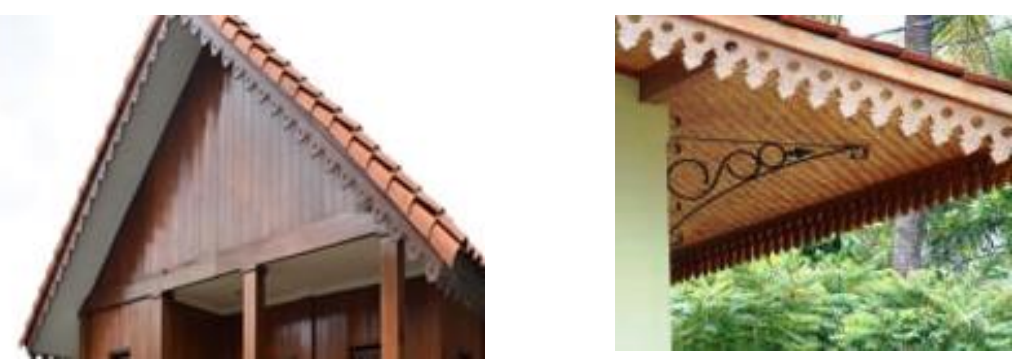

FIGURE 7. Ornamental fascia board

There are several forms of roofs in Betawi houses, including gable roofs and pyramid roofs. Gable roofs with water runoff at the front are used in kebaya houses, where the roof when viewed from the side is shaped like a kebaya fold. While the saddle roof with water runoff on the side is used in the Kandang house and the Coastal house. Joglo is usually almost the same as other Javanese traditional houses that use a pyramid-shaped roof. Each Betawi house has something in common, namely using a ornamental fascia board with balang tooth ornament to decorate the edge of the roof.

6. Color. Some Betawi houses have characteristics that use bright colors especially the yellow and green colors that often dominate Betawi houses.

\section{The Application of Betawi Architecture Concept}

Updating the Betawi architecture is a sustainable step in appreciating the work of the nation itself. To improve the knowledge of Nusantara architecture especially Betawi architecture is a step to create the novelty of Betawi architecture in current designs. Updating Nusantara Architecture must begin with dismantling ourselves and changing the mindset and being aware of the uniqueness of our Archipelago Architecture, including being in a climate of two non-lethal seasons, having structures and constructions that are anticipatory to earthquakes, and others. To create Nusantara architecture especially Betawi architecture visible, of course, it does not have to be limited in the form of a building, but it can also be in the interior and exterior decoration, spatial planning patterns and spatial concepts, as well as the diversity of philosophies behind the formation of archipelago architectural buildings.

\section{The Sociocultural of Setu Babakan}

In general, the Setu Babakan community still carries out cultural ceremonies in their entirety, especially at RW 08 (the majority of Betawi residents are native). Meanwhile, RW 05 and RW 07 rarely do it (mixed residents) and RW 06 does not do any activities (the majority are migrants). Cultural activities that are still being carried out include: 1) Traditional ceremonial activities related to customs and ways of life (reciting, tamat quran, ngubak empang, community service). 2) Traditional ceremonial activities related to the human life cycle (wedding ceremony, seven months, akekah, shaving, circumcision, community service, ngubak empang). 3) Ceremonies related to religion [reciting the Qur'an, completing the Qur'an, Eid al-Fitr, Eid al-Adha, Nispu, the Prophet's birthday, death].

\section{Betawi Cultural Village}

Betawi Cultural Village is cultural tourism in Setu Babakan, which is a tourism activity that aims to regenerate traditional values which are packaged attractively. Betawi Cultural Village become models of Betawi Architecture implementation design in Setu Babakan. The caracteristics architecture Betawi combine with the modern architecture forms the modern-traditions architecture, one of the various architecture style of postmodern. The main building of Betawi Cultural Village seen as Management Building which form three levels modern-tradition buildings in Betawi Architecture. The building has langkan as a terrace of a house. Cultural tours that are served directly at Betawi Cultural Village are:

1. Exercises and performances of Betawi arts

Betawi art exercises and performances are held regularly every Sunday from 09.00 - 17.00 WIB. Traditional Betawi music, dance, and theater exercises held in the open theater arena as well as 
Betawi Beksi silat training are held in the morning for teenagers and children. For musical performances (Gambang Kromong, Samrah, Gambus, Qasidah, Hadroh, Marawis, Keroncong Betawi, Tanjidor, etc.), acting (Lenong Preman, Topeng Betawi, etc.), Wayang Kulit Betawi, usually held on Sunday afternoons with a schedule determined by the manager of PBB Setu Babakan.

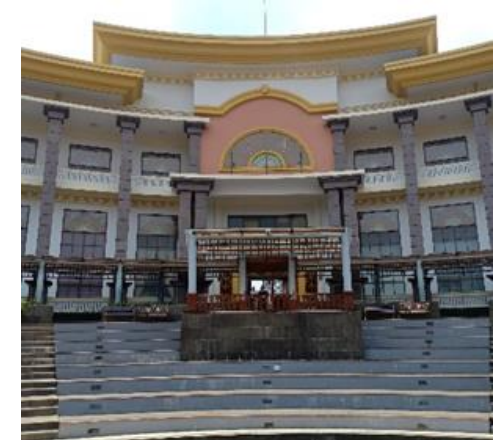

FIGURE 8.A building in Betawi Cultural Village

2. Betawi cultural processions such as wedding ceremonies, circumcisions, khatam Qur'an, aqiqah, seven months, trampling the ground, and cadres whose schedules are ceremonial/incidental once a year in the middle of the year.

3. Introduction to housekeeping (typical Betawi houses/buildings, including large door and window models and grasshopper tooth motifs on the edges of the roof of the house). For the introduction of culinary services, various home industry products in the form of traditional Betawi food are available at Setu Babakan including egg crust, laksa, fried bean sprouts, Gado-Gado, Soto, pecak fish, geplak, dodol, geplak, wajik rangi, rengginang, tape Uli, layers of trays, dumplings, and pletok beer. Introduction to fashion (typical Betawi clothing).
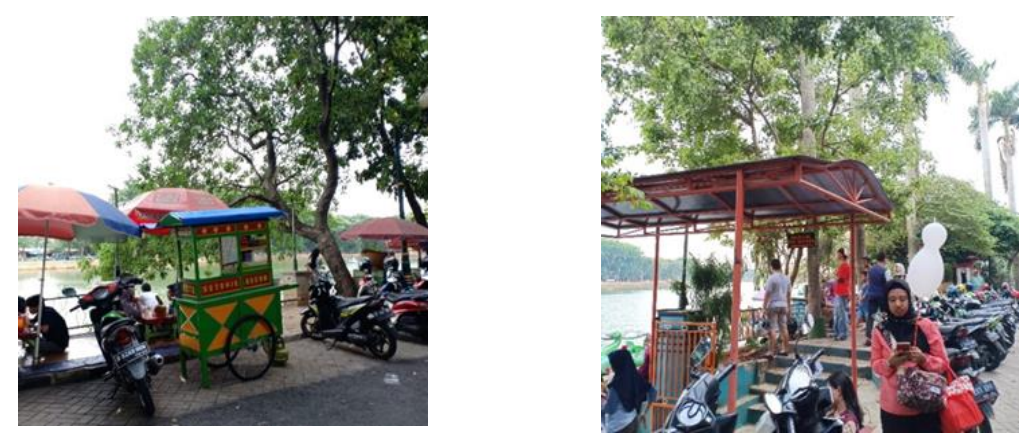

FIGURE 9. Culinary Tour

4. Water Tourism

Water tourism is an effort to increase tourist attractiveness from the aspect of water sports that can attract tourists. The depth of Setu Babakan itself currently ranges from two to five meters. Water tours that can be enjoyed in the Betawi cultural village today are Water bikes, canoeing/rowing, and fishing.
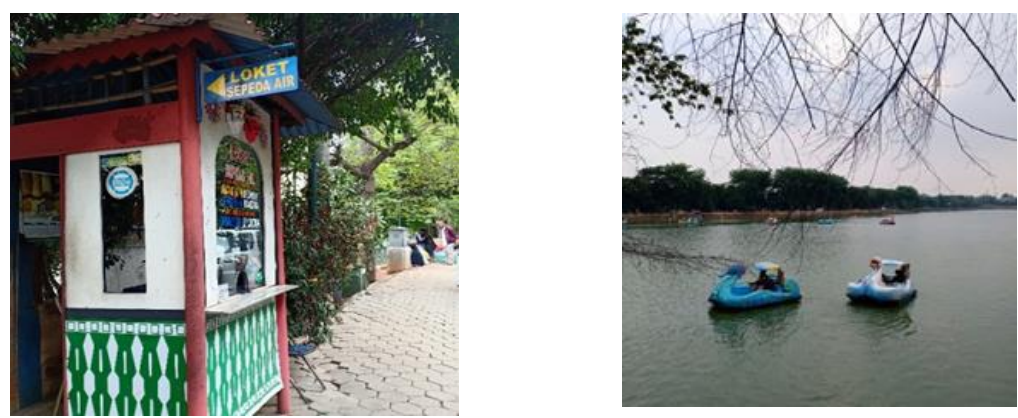

FIGURE 10. Water Recreation Tour 
In general, Setu Babakan is managed by the Betawi Cultural Village Unit under the Cultural Office of the South Jakarta City Government. However, for the management of entrance tickets, playing facilities, parking, and order for traders, it is left to the Betawi Cultural Village Social Movement Task Force, the local community who voluntarily participates in the management of the Betawi Cultural Village. Entrance fees are not charged for visitors who come on foot or ride a bicycle. For visitors visiting by motorbike, there is an entrance fee of IDR 2,000 per motorbike and IDR 5,000 per car for visitors visiting by car. The average fee charged for enjoying the game facilities at Setu Babakan is IDR 5,000 per person. Visitors can park their private vehicles anywhere along the Setu Babakan bank. However, if a visitor's private vehicle is parked in certain parts of Setu Babakan, a fee of IDR 2.00 will be charged.

The basic concept of planning the Betawi Cultural Village, in general, is to increase the dignity of the Betawi community through spatial planning. The spatial planning within the boundaries of the community's life is based on the developed traditional and socio-cultural values. The application of traditional Betawi architectural forms to strengthen regional characteristics and identity. (Proposal for the Development of the Betawi Community Cultural Village, 1998). Generally, the 2000-2010 Betawi Cultural Village Master Plan is divided into 2 major groups, namely: Dynamic Zones and Static Zones. The Masterplan 2010 for Betawi Cultural Village can be clarified as follows: A. Dynamic Zone 1) Village Zone, as a village area where the dynamic growth of Betawi culture still maintains the most valuable Betawi cultural values of the community. Zones are evenly distributed over open lands (gardens and yards) belonging to residents. Community gardens/yards as agrotourism objects also function as economic support for the population through community guidance and empowerment. Area development is carried out by referring to water catchment areas, and the provisions for the area that can be built with KDB (Basic Building Coefficient). 20\% of the area for mixed-use areas can be increased to $25 \%$ 2) Support facilities zone (3.15\%), as an area that supports the activities of the population (education, religion, health). B. Static Zone 1) The art zone $(1.21 \%)$, which is the area to accommodate Betawi art activities (dance, drama, music) 2) The historical zone $(1.33 \%)$, which is the area that accommodates Betawi historical activities and their development as well as historical values from past until now. 3) Religious zone (0.36\%), an area that accommodates religious activities. 4) Agro tourism zone (48.8\% and open space), an area that serves and accommodates fruit tree plantation (agro) tourism trips and enjoys garden products and typical regional plant processing. 5) Water tourism zone (green open space), Setu Babakan, and Setu Mangga Bolong water resources, is an area that accommodates water tourism activities (rowing, fishing) as the main recreation object (Core Destination) which can provide economic and ecological value. 6) Industrial Zone, an area that protects and develops existing industries (home industry). This area will spread within the Betawi Cultural Village area.

\section{CONCLUSION}

Betawi culture as the local culture of the capital city of Jakarta is increasingly marginalized, even no longer the majority in its own area. The results of observations on the site of 879 housing units were divided into original houses as much as $22.75 \%$ characterized the Betawi architecture and $77.25 \%$ did not characterize Betawi architecture. The application of Betawi Architectural Ornaments in the Setu Babakan area, especially seen in the following elements: 1)roofs; 2) pendopo or front porch of the house; 3) Langkan (Betawi balustrades), being a guardrail between the terrace and the yard, the spear ornament on the railing symbolizes mountains, peaks, higher achievements, authority and strength to protect the house; 4) Gigi Balang and iron console, this Balang Tooth Shape has a message to deal with every problem in his life, such as a resilient and diligent grasshopper; 5) Rectangular blind windows, the doors and windows are wooden frames arranged on an oblique side and horizontal lines; and 6) Semicircular Window, this semicircular window is the same as the 4 rectangular mirror window above, the difference is in the window shape decoration, 7) furnitures and hanging lamps; and 8) colors.

Betawi culture is a valuable asset that must be preserved so that the next generation can still enjoy the original culture of the Jakarta tribe. The architecture of Betawi should be positioned as a source of inspiration for architectural knowledge. Updating the Betawi architecture is a sustainable step in appreciating the work of the nation itself. The application of Betawi architecture concept in architecture buildings today should be packaged in a more modern and contemporary form. To create Nusantara architecture especially Betawi architecture visible, of course, it does not have to be limited in the form of a building, but it can also be in the interior and exterior decoration, spatial planning patterns and spatial 
concepts, as well as the diversity of philosophies behind the formation of archipelago architectural buildings. Hopefully in the future Nusantara Architecture can enrich and introduce the treasures of architecture in Indonesia and in the world.

\section{REFERENCES}

[1] [1] Mochtar, M.S, Sarwadana, S.M, Alit S, C.G. 2012. Identifikasi Pola Permukiman Tradisional Kampung. Budaya Betawi Setu Babakan, Kelurahan Srengseng Sawah, Kecamatan Jagakarsa, Kota Administrasi Jakarta Selatan, Provinsi DKI Jakarta. E-Journal Agroekoteknologi Tropika Universitas Udayana, ISSN: 2301-6515, Vol 1[No.2] Oktober 2012.

[2] Francis D. K. Ching. 2008. Ilustrasi Konstruksi Bangunan [Edisi 3]

[3] Harun IB, Kartakusuma H, Ruchiat R, dan Soediarso U. 1999. Rumah Tradisional Betawi. Jakarta [ID]: Dinas Kebudayaan Daerah Khusus Ibukota Jakarta.

[4] Koentjaraningrat. 2005. Pengantar Antropologi II. Jakarta: Rineka Cipta.

[5] Sitepu. 1992. Strategi Pemerintah DKI Jakarta Mempromosikan Kampung Setu Babakan Betawi Sebagai Daerah Tujuan Wisata Internasional. Jakarta [ID]

[6] Soeroto, Myrtha. 2003. Menuju Arsitektur Indonesia. Jakarta: PT Balai Pustaka.

[7] Sitepu. 1992. Strategi Pemerintah DKI Jakarta Mempromosikan Kampung Setu Babakan Betawi Sebagai Daerah Tujuan Wisata Internasional. Jakarta [ID]

[8] Wardiningsih, Sitti. 2014. Lanskap Budaya Wisata Budaya Betawi [Studi Kasus Kota Tua Jakarta Kota]. Jurnal NALARS Vol. 13 [No. 2] Juli 2014 Halaman:117-122

[9] Wardiningsih, Sitti. 2005. Rencana Pengelolaan Lanskap Perkampungan Budaya Betawi di Setu Babakan-Srengseng Sawah, Kecamatan Jagakarsa, Jakarta Selatan, Thesis Program Pascasarjana Institut Pertanian Bogor. 